\title{
Kinship Without Words
}

\author{
Robert Layton ${ }^{1}$
}

Received: 7 August 2019 / Accepted: 14 February 2020 / Published online: 2 April 2020

(c) The Author(s) 2020

\begin{abstract}
This article seeks to identify at what point in hominid evolution language would have become adaptive. It starts by recalling the distinction between kin-selected altruism and reciprocal altruism, noting that the former is characteristic of social insects while the latter is found among some species of social mammal. Reciprocal altruism depends on the exchange of information assuring partners of the other's continued friendly intent, as in the iterated prisoner's dilemma. The article focuses on species that practice "fission-fusion": social behaviour, where the alternation between larger and smaller parties creates greater uncertainty as to individuals" continued commitment to reciprocity. The greatest uncertainty arises in "atomistic" fission-fusion, where individuals leave and join foraging groups independently. Chimpanzees, bonobos, and human huntergatherers practice this type of social behaviour. There is less uncertainty where the smaller social unit is an extended family, as among vampire bats, chacma baboons, and savanna elephants. A comparison of the repertoire of calls and gestures among these species indicates that chimpanzees and bonobos have the largest repertoires. I then point out that, thanks to the higher proportion of meat in the diet, hunter-gatherers must live in far more dispersed communities than chimpanzees or bonobos, yet they practice more complex patterns of cooperation and reciprocity. This, I argue, created a social environment in which language became particularly adaptive. Homo heidelbergensis is identified as the key species in which language could have originated, during the transition between the Lower and Middle Paleolithic.
\end{abstract}

Keywords Call systems $\cdot$ Information theory $\cdot$ Language $\cdot$ Reciprocal altruism $\cdot$ Social evolution

\section{Introduction}

In their rationale for the 2019 research workshop on Revisiting the Evolution of Kinship, the organizers noted that kinship is central to human social life, bringing together the biological facts of reproduction and relatedness with the social facts of how family relationships are categorized. The evolution of more complex kinship systems was likely to have played a key role in expanding the social universe of early humans or their hominin forebears. The rationale concluded that the relevance of kinship stretches out to the points of contact, in genetics, between biological systems of descent and social regulation of mating; and, in primatology, to the gradual extension of individual recognition beyond immediate kin. This article focuses on the last of the issues identified.

Robert Layton

R.H.Layton@durham.ac.uk

1 Durham Cultural Evolution Research Centre, University of Durham, Durham, UK
Given the challenge of reconstructing the early coevolution of human kinship and language, I decided that a useful approach would be to look at kinship recognition in a selection of other species, to see what could be achieved without language, and then ask when the complexity of human kinship may have reached a point at which calls and gestures would have become inadequate.

\section{Some General Principles}

\section{Two Central Issues: Altruism and Communication}

In the neo-Darwinian theory of social behavior two forms of altruism have been identified. In a bee or ant nest, all the "workers" are offspring of the same queen. If a few sacrifice their lives to save the colony, the survivors are likely to carry the same "altruistic gene" and the practice is favored by natural selection (Hamilton 1964). In reciprocal altruism (Trivers 1971, 1985), the reward is delayed. If one individual has more of a needed resource than the other, (s)he shares 
it, in the expectation that when the situation is reversed, the former recipient will share with the former donor. Both individuals benefit in the long run if the reciprocal exchange is repeated, but such a relationship depends on mutual trust. Reciprocal altruism can take place between kin. In nonhuman species where one sex disperses and the other remains in its place of birth, the opportunities for mutual trust to develop between members of the non-dispersing sex are much greater. Unlike the form of "altruism" seen in social insects, however, close kinship is not necessary for reciprocal altruism to be favored by natural selection. In small-scale human societies, relationships based on reciprocal altruism are often represented in terms of kinship, but develop between friends and neighbors. Such relationships are said by anthropologists to be based on "social kinship."

Trivers (1971) argued that reciprocal altruism will become an evolutionarily stable strategy where, for example, there is a risk of death, such as from starvation, and where it is impossible to predict which individual will be successful on any one occasion, yet if those who are successful in obtaining food get more than they immediately need, and share it with a neighbor. Reciprocal altruism will only develop where the individuals have a stable relationship in which mutual trust can develop. It is facilitated by a long lifespan and a low dispersal rate (geographical stability of residence). Reassurance of friendly intent through low-cost signals can play a vital role in sustaining mutual trust. The South American vampire bats (Wilkinson 1984) discussed in Trivers (1985, pp. 363-366) are an exemplary case. These bats feed by scratching the hides of cattle and licking up the blood, but often fail to feed and can starve to death after missing only two to three nightly meals. One of Wilkinson's remarkable findings is that previous reciprocal food-sharing is eight times more important than biological kinship for predicting donation rates, and vampire bats that feed more nonkin "maintain a larger and more robust network of donors" (Carter and Wilkinson 2016, p. 45). In social anthropological terms, "social kinship" is very important among vampire bats.

\section{Signaling and Communication}

Scott-Phillips argues that the conveying of information should not be considered as an intrinsic feature of biological signals. He considers (2008, p. 388) defining a biological signal as "any act or structure that affects the behavior of other organisms and which has evolved to have that effect." Thus, the physical size of an opponent is a cue that signals the risk of engaging in combat. On the other hand, ScottPhillips concedes that a physical push is not a signal. This is a crucial distinction. The yellow and black stripes on a wasp's abdomen can be considered a signal, whereas the wasp's sting is a physical act. Reciprocal exchange is not communicative, Scott-Phillips argues, because each transaction places a material obligation on the recipient to return the act. However, the exchange of friendly greetings between partners in reciprocity is, in my assessment, a prime example of communicating information about the probable future of the relationship. Kersken et al. (2019) define communicative gestures among chimpanzees as those that are "mechanically ineffective."

Godfrey-Smith (2007, 2015), in contrast to Scott-Phillips, prefers Shannon's (1948) original characterization of signals: the function of a message is to transmit information from sender to receiver, and hence reduce uncertainty. Cherry (1966, p. 171), following Shannon, defined the information conveyed in a signal as the extent to which the signal removes doubt in the mind of the recipient. It does so by choosing one from among the set of calls in the recipient's vocabulary in preference to any of the alternatives. Cheney and Seyfarth (2007, p. 76) write of baboon signals: "In stable social groups where individuals interact frequently, such uncertainty [as to another's intentions] should favour the evolution of reliable, honest signals that provide accurate information about the signaller's probable behaviour." This article will review whether greater uncertainty in social relationships leads to a larger vocabulary of signals.

In social species of bird (Griesser et al. 2017) and mammal, kin are recognized and cooperation between kin enhances their survival. There is also evidence from a range of different species for reciprocal relationships beyond close kin. The first section of the article exemplifies what can be achieved without language. If vampire bats, elephants, baboons, and chimpanzees can evolve kin-based social interaction without language, and move beyond kin to create social relationships with nonkin, this poses two questions that I will address toward the end of the article: (1) when and (2) why did our ancestors start to use language to talk about social relationships?

Hockett and Ascher defined an animal call system as follows:

There is a repertory of a half-dozen or so distinct signals, each the appropriate vocal response... to a recurrent and biologically important type of situation.... The signals of a call system are mutually exclusive in the following sense: an animal, finding himself in a situation, can only respond by one or another of the calls or by silence. (1964, p. 139; emphasis in original)

More recent research on call combinations, and the question of whether this phenomenon throws any light on the evolution of language was pioneered by Zuberbühler (2002); see Crockford and Boesch (2005) for a more detailed study.

Among mammals, calls provide information in a situation of uncertainty (warning of an approaching predator, for example, or confirmation of friendly intent toward other 
members of the group). In the context of this article, calls remove uncertainty during social interaction. substantially on mutual aid to overcome difficulties such as illness, injury, or the birth of a child which temporarily

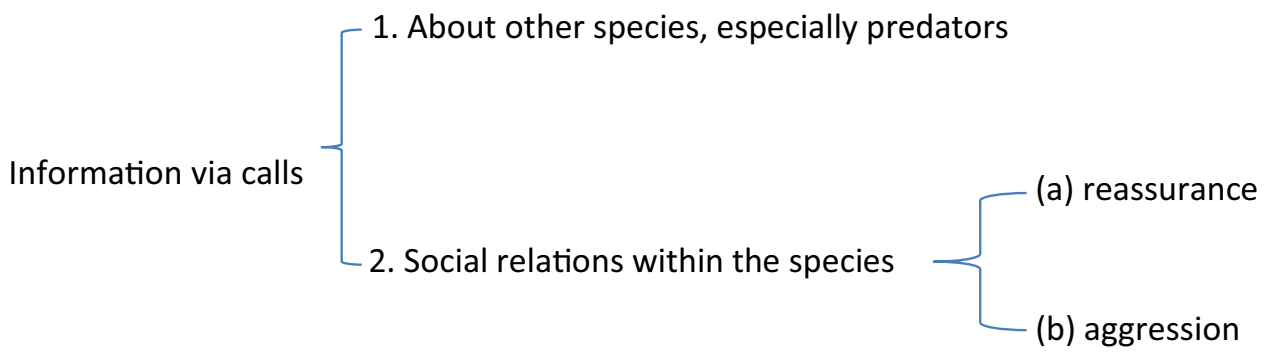

An important distinction is made between calls that are emitted spontaneously and those emitted intentionally. By spontaneous, I mean "performed or occurring as a result of a sudden inner impulse or inclination and without premeditation or external stimulus" (The New Oxford Dictionary of English (1998)). Omitting that last phrase, one could write of a person laughing spontaneously at someone's joke, being unable to help oneself from laughing rather than laughing in a forced or contrived way. Such spontaneous calls can still communicate information to a listener. Fischer and Price (2017) argue that nonhuman primates do not seem to attribute mental states to others, and therefore do not appear to express or understand communicative or informative intent. Primates do, however, understand the referents of calls such as alarm calls uttered by others when a predator is sighted, and respond accordingly. Fischer and Price concede that, although the structure of primate vocalizations is largely innate and related to the "affective/motivational state" of the caller, there is evidence that individuals have some control over uttering their calls; the calls are not, in the sense used here, entirely spontaneous.

\section{Costly and Moderately Priced Signals}

A popular notion in the study of animal communication is that signals must be costly to be reliable, by preventing cheating. This approach originated in the work of Zahavi (1975), who argued that the male peacock's tail is a reliable signal of reproductive fitness, because a less-healthy peacock would not have the surplus energy available to invest in a splendid tail. This approach has been adopted to explain meat sharing in a hunter-gatherer band: only a good hunter could catch enough meat to share it around the camp. By sharing it, the good hunter is signaling his reproductive fitness (Hawkes and Bliege-Bird 2002, pp. 60-61; but see Maynard-Smith 1994).

My own approach to signaling in human communities is colored by my $\mathrm{PhD}$ fieldwork in a French village ("Pellaport"). In 1969, when a large proportion of households were small agricultural enterprises, kin and neighbors relied depleted household labor (Layton 2000, Chap. 4). Those who developed a reputation for generosity or for holding themselves apart were given nicknames, affectionate in the first case, mocking in the second. The signals of goodwill were to be amiable toward your neighbors, to say "good day" to those you met, to exchange a joke with friends, and to be ready to help someone in difficulty. Holding oneself apart could be expressed in speaking ponderously, giving one's words more weight than they deserved, walking past another without exchanging a greeting, or not inviting a neighbor into one's house for a drink. The high-cost signaling of the peacock's tail to guarantee its reproductive potential is functional because verifying the peacock's reproductive health would otherwise be difficult. The low-cost signaling of daily human interaction in Pellaport, and peasant communities generally, is viable because its reliability can be frequently put to the test, simply by asking someone to assist in a laborious task. Primate signals: the lip smacking of a chacma baboon signaling friendly intent, the "wahoo" of a male signaling aggression, are of the same basic type as the signals used in Pellaport. Their low cost is intrinsic to their function; a signal that cost more to give than did the material interaction to which it relates would be pointless.

There is, then, a deep connection between the importance of reciprocal altruism as a means of extending social relationships among mammals, in the absence of the close biological kinship that exists among social insects, and the importance of signals as a means of confirming commitment to reciprocal relationships.

\section{Fission-Fusion Behavior}

The case studies outlined in this article are all of species that practice fission-fusion social behavior. Fission-fusion behavior occurs when individuals of a social species fluctuate between membership of smaller parties and larger social units that then subdivide again. This introduces a degree of uncertainty about the current state of social relationships that is absent in other social species. 
Species with fission-fusion social systems include elephants, herd-forming bovids, whales, and among primates, chimpanzees, bonobos, spider monkeys, gelada, and chacma and hamadryas baboons, drills, and mandrills. Authors of the case studies summarized here follow Kummer (1968) and Van Schaik and Kappeler (1993) in distinguishing two types of fission-fusion systems:

(a) Molecular a small stable basal unit (reproductive or family) joins and leaves less stable, larger groupings. Savanna elephants, gelada, and hamadryas baboons are of this type.

(b) Atomistic individuals leave and join foraging groups independently. Chimpanzees, bonobos, and human hunter-gatherers practice this type of social behavior.

In the following paragraphs I summarize four case studies, looking at the relationship between patterns of social interaction, sources of uncertainty in social relationships, and the use of calls and gestures to reduce this uncertainty.

\section{Vampire Bats}

South American vampire bats (Desmodus rotundus) practice female philopatry and male dispersal (Wilkinson et al. 2019). Colonies, the fusion unit in vampire bat fission-fusion behavior, comprise the members of several matrilines. Female-female associations are therefore more common than male-male ones. Female common vampire bats develop stable relationships with both kin and nonkin in the colony that last for many years (Carter and Wilkinson 2016, p. 49). Dominant males defend colonies of related females, as among gelada and chacma and hamadryas baboons (Dunbar 1989; Swedell and Plummer 2012).

The number of different calls among vampire bats appears to be limited. In all bat species, "pups" produce an "isolation call" that enables mothers to recognize and retrieve them if, for example, they have fallen to the ground (Carter and Wilkinson 2016). In three species of vampire bats adults also produce isolation calls that vary between individuals, which seem to allow bats to recognize "group-mates."

\section{Chacma Baboons}

Like vampire bats, baboons practice a "molecular" form of fission-fusion behavior. Cheney and Seyfarth (2007, p. 285) carried out a long-term study of a troop of about 80 chacma baboons (Papio ursinus) living in the Okavango Delta. ${ }^{1}$

\footnotetext{
${ }^{1}$ Cheney and Seyfarth's Baboon Metaphysics is a wonderful book, and I was saddened to read that Dorothy Cheney had died while I was working on this article.
}

They note that baboons live in considerably larger groups than do chimpanzees. Most live in multi-male, multi-female groups that typically include eight to nine matrilineal families, yet each individual also maintains a complex network of relationships with both biological kin and nonkin. Within the group there is a linear dominance hierarchy of males that changes frequently and a linear dominance hierarchy of females and their offspring that can be stable for generations. Male baboons are much bigger than females. They reach adulthood at around 9 years old and most then migrate to a neighboring group. Males usually die at around the age of 12, soon after losing their high status in the dominance hierarchy. Females remain in their natal group all their lives, and form the core of baboon social organization. They lead more peaceful lives, often surviving until they are at least 20 years old.

For baboons, group living is essential: it enables females to defend food resources and it reduces the risk of predation. Unlike in some other species, low-ranking female baboons are able to reproduce, i.e., their ovulation is not suppressed. Females from low- and high-ranking families (who are not close kin) groom each other and form alliances. Over a year, a female can have "dozens" of grooming partners, including biologically unrelated ones. Grooming partners tolerate each other at feeding sites, huddle together on cold days, and support each other in aggressive alliances. As among vampire bats, grooming is an important signal of the intent to continue a relationship.

Males and females can form short-term relationships that lead to reproduction, and long-term friendships that lead to cooperative child-rearing. Most infanticide is practiced by incoming males who rise to the alpha position. Lactating females will seek protection for their infant by forming a friendship with a resident adult male, most often the one who was alpha male when their infant was conceivedthis implies, to me, that female baboons have some idea who fathered their offspring. Friendships are the strongest and most enduring relationships formed between male and female chacma baboons. A pair of friends forage and sit together, grooming each other frequently. A male "babysits" while his female friend is foraging and allows his friend's infant to pull his tail, sit on his head, and slide down his back. A friendship ends when the infant is weaned, but, if an infant is orphaned, the mother's friend will take on the role of primary adult companion.

\section{Calls and Gestures}

Baboons must be able to predict how other members of the troop will act, so they need information. "[E]ven though baboons lack language, their vocal communication is rich enough in meaning to tell us a great deal about what they think" (Cheney and Seyfarth 2007, p. 14). "A reasonable 
Table 1 Chacma baboon signals identified by Cheney and Seyfarth (2007)

\begin{tabular}{|c|c|}
\hline \multicolumn{2}{|l|}{ Calls } \\
\hline Wahoo & $\begin{array}{l}\text { Aggressive male call. Since there is a predictable relationship between a male's rank and the quality of his wahoos, there is } \\
\text { no need for actual fighting }\end{array}$ \\
\hline Lip smacking & Friendly intent. May be used by male entering "harem" to solicit friendly interaction from resident males and juveniles \\
\hline Grunts & $\begin{array}{l}\text { Uttered to appease another female when approaching to handle her infant. Also uttered by dominant female as a sign of } \\
\text { reconciliation after a dispute } \\
\text { Threat grunt indicates willingness of dominant female to intervene in an argument } \\
\text { Move grunt uttered to other members of foraging party when ready to move on } \\
\text { Infant bark indicates benign intent }\end{array}$ \\
\hline Alarm calls & Alarm calls uttered near water appear to distinguish between lion and crocodile \\
\hline Bark & $\begin{array}{l}\text { Fear bark often emitted by low-ranking females when a higher-ranking female tries to handle their infant } \\
\text { Contact bark uttered by any individual when lost or separated }\end{array}$ \\
\hline \multicolumn{2}{|l|}{ Gestures } \\
\hline Presenting rump & Male gesture of submission \\
\hline Head bobbing & Female challenge to another female \\
\hline
\end{tabular}

aThe term "harem" is misleading, because the females constitute the enduring core while males come and go

guess would be [that baboons have] around fourteen vocalisations" (2007, p. 253).

Baboons can recognize the individual identity of another who makes a call. Playback experiments have indicated that they can also recognize an unlikely sequence of two recorded calls, such as a subordinate individual apparently challenging a dominant one and can classify others according to their membership of a matriline. Such contextual information enhances the communicative value of calls (see Table 1).

\section{Savanna Elephants}

Male and female African savanna elephants (Loxodonta africana) live almost entirely different social lives once the males reach independence, but both have large networks of social relationships. The matrifocal extended family is the basic social unit. It consists of "an adult female and its offspring, or two or more closely related females and their offspring.[Elephant] families usually number from 4 to 15 individuals, their activities are closely coordinated, and large bulls seen with them are generally attached loosely and temporarily" (Moss et al. 2011, p. 205). As in vampire bats, longevity facilitates the development of trust between individuals. African elephants live into their 70s, 20 years after they have ceased breeding. This also facilitates allomothering (Lee et al. 2016).

For an elephant, the advantages of living in a family include shared infant care, protection, and active defense against predators that threaten the young. At any time, the majority of the family are in one place in the same activity, e.g., feeding, walking, drinking, or resting. They practice "affiliative behavior" such as greeting or touching one another, and cooperative behavior such as caring for each other's infants.

\section{Fission-Fusion Behavior}

Fission-fusion behavior among savanna elephants is seen in families temporarily splitting or joining other families for a period, and families from time to time associating with adult males. "Immigration into families appeared to be extremely rare" (Moss et al. 2011, p. 210). Bond groups form when elephant families join each other for an hour to several weeks, during which members regularly practice affiliative behavior such as greeting and touching. Enthusiastic greetings are exchanged when bond groups assemble. Bond groups appear, according to Moss et al., to be partly based on shared kinship, and partly on shared history, experience, and friendship between the matriarchs. Both calves and adults suffer less mortality when in larger groupings.

\section{Communication}

Among elephants, interaction between kin is facilitated by a complex pattern of calls and physical contact. Family members call to reinforce bonds between relatives and associates, to care for calves, to reconcile differences between "friends," to defend close associates, to form coalitions against aggressors and predators, to coordinate movements, and to keep in contact with one another over great distances (Moss et al. 2011, p. 124). Elephants can send and detect auditory signals over several kilometers, and discriminate among individual "voices" up to $2 \mathrm{~km}$ away. They communicate through low frequency rumbles, higher frequency trumpets, snorts, barks, roars, grunts, and cries. Poole identifies ten primary call types used in communication and various subtypes that she considered are better regarded as graded rather than discrete calls. 
Most calls and gestures by females and young give emphasis to the social unit, while male calls tend to advertise their sexual state, identity, and rank (Moss et al. 2011, p. 125). Adult females greet and touch each other. Calves respond to reassurance and comfort given by mothers and allomothers with "little greeting rumbles" when, for example, they are touched in a caring way by an older member of their family. Observation showed clearly that females can distinguish their family and bond group members from other elephants on the basis of how they react to the contact calls of others.

At around the age of 14, a male Amboseli elephant leaves its natal group. Thereafter, "peer-peer contact and establishing familiarity through association" seem to be priorities for the young male (Moss et al. 2011, p. 265; my emphasis). Large males have at least one close friend, who is similar in age. Adult females may chase away unrelated males, but males that grew up in the family are tolerated or even greeted when they return.

\section{Key Points to Note in Non-hominin Examples}

Social living is particularly adaptive in certain environments. Among birds, "A high enough but variable level of resources throughout the year favours the evolution of persistent kin groups and cooperation outside the reproductive context" (Griesser et al. 2017: Discussion). Among elephants and baboons, much larger social groups are found in savanna than in wooded environments. African forest elephants live in smaller groups of two to three, typically consisting of a mother and two offspring (Moss et al. 2011, p. 233). This may be due to the absence of predators and/or a different distribution pattern of food, with competition for dispersed high-quality foods in forest environments. Comparison with baboons suggests the absence of predators is the crucial factor (see Dunbar 1989, p. 137; Swedell and Plummer 2012, p. 1171; Willems and van Schaik 2017 for a general survey and discussion).

Kinship is as much about social roles as it is about biological relatedness, and familiarity is the basis for building trust. Seyfarth and Cheney (2012, p. 154) use the term "friendship" to describe "enduring social bonds that are not directly related to mating," noting that friendships are found among horses, hyenas, and dolphins as well as among primates. They find that among males, those with allies have superior competitive ability, higher dominance rank, and improved reproductive success while females with allies experience less stress, higher infant survival, and a longer lifespan. Extending reciprocal relationships beyond close kin is by no means unique to human society.

Quite complex social interaction can therefore be achieved without language. Nonetheless, compared to language, all of the call systems considered in this article have a very restricted range of referents. As Gregory Bateson wrote many years ago, "It seems that the discourse of nonverbal communication is precisely concerned with matters of relationship - love, hate, respect, fear, dependency, etc." (Bateson 1973, p. 388). This raises the question, what differences in social organization that distinguish hominins from chimpanzees might have created even greater uncertainty and hence made a more complex system of communication adaptive?

\section{Chimpanzees (Pan troglodytes) and Bonobos (Pan paniscus)}

\section{Male Versus Female Social Lives}

In contrast to chacma baboons and elephants, a chimpanzee or bonobo community is made up of a core of related males. Among chimpanzees such males cooperate to defend access to the ranges of several females against males from neighboring groups. Females may transfer permanently from their natal community to a neighboring one (Goodall 1986, pp. 86-87). A male chimpanzee starts to leave his mother when he is about 8 years old. "As adolescence progresses" (Goodall 1986, p. 166) he spends more time with adult males and sexually receptive females.

Unlike baboons and elephants, chimpanzees and bonobos practice atomistic fission-fusion. The female core whose members normally forage (or roost) together, seen in the case studies considered so far, is absent. Goodall reported that, at Gombe, each individual tends to have a core area that is frequently used, and other parts used only occasionally, e.g., when trees are fruiting. The longest distance covered in a day during Wrangham's two-year study was $10.7 \mathrm{~km}$ by an adult male, but the next day this individual only travelled $2.4 \mathrm{~km}$. Males typically travel $4.9 \mathrm{~km}$ in a day, visiting the boundary area of the community's territory about once every 4 days. Females travel an average of $3 \mathrm{~km}$ per day (Goodall 1986, pp. 209-211). When food is scarce, Gombe chimpanzees tend to forage alone or in small groups; when food is plentiful, many individuals forage together. The presence of many sexually receptive females leads to a dramatically higher level of association between males and females (Goodall 1986, pp. 155-158). Consequently, "the membership of temporary parties is constantly changing. Adults and adolescents can and do forage, travel and sleep quite on their own, sometimes for days at a time" (Goodall 1986, p. 147). A chimpanzee

rarely sees all the members of his community on the same day and probably never sees them two days in succession... There is always uncertainty: it is never 
possible for a chimpanzee, upon wakening in the morning, to be quite sure whom he will encounter during the day. (Goodall 1986, p. 147; emphasis in original)

Among bonobos, foraging parties contain both male and female members, although males sometimes forage alone (Kano 1992, p. 71). Bonobos also practice an atomistic form of fission-fusion.

Within a bonobo community, individuals form temporary subgroups or "parties" that travel and forage separately.... Parties are unpredictable in size (ranging from one individual to the entire community), duration (lasting from several minutes to several days) and composition (because animals do not always form a party with the same individuals). (Schamberg et al. 2016, p. 110)

Atomistic fission-fusion entails that "individuals must maintain relationships with individuals whom they may encounter irregularly and coordinate their behavior and movement with out of sight individuals" (2016, p. 110). Bonobos use vocalizations facultatively (by choice) to maintain contact and coordinate movement with out-of-sight individuals. In other words, these calls are not uncontrolled or spontaneous. Chimpanzees also use vocalizations to coordinate with out-of-sight individuals and appear to modify their call production based on knowledge of which individuals are nearby.

At Gombe,

When a chimpanzee rejoins his or her companions after a long separation, levels of arousal are apt to be high. In the case of family members or other individuals with close, supportive bonds, the excitement is expressed through embracing, holding, patting, screaming and so on. (Goodall 1986, p. 332, see also pp. 366-367)

When a competitive dominance relationship is involved, violent hostility is expressed. However, peaceful interaction is more frequent than aggression. "Chimpanzees have a deep-rooted need for contact with a friendly conspecific in times of physical or emotional stress" (Goodall 1986, p. 358). "Here is no doubt that reassurance plays a major role in conflict resolution" (1986, p. 361).

Goodall's theory of how kin selection can evolve into altruism toward non-relatives is supported by Wilkinson's observations of vampire bats. She writes: "altruistic behavior toward non-kin is dependent, genetically, upon firmly established helping behaviors among close kin" (Goodall 1986, p. 377), and chimpanzees can remember who helped them on previous occasions.

\section{Calls and Gestures}

As suggested by Aureli et al. (2008), in types of fission-fusion societies that generate more uncertainty as to others' dispositions (because they are encountered less often), there may be a larger repertoire of calls and gestures. The question, "how many calls and gestures do chimpanzees have?" has been closely investigated. Goodall (1986, p. 127) distinguished 32 calls and grouped them according to the 13 emotions or feelings with which they are most closely associated. These include fear, anger, distress, sexual excitement, social excitement, and sociability. One or two calls appear more than once, e.g., scream, associated with both anger and social excitement. (This phenomenon proved to be more widespread than Goodall noted. See, for example, Crockford and Boesch summarized in Table 2.) Crockford and Boesch (2005), working in the Tai Forest, distinguished 15 "pure" types of call, together with drumming. Cat Hobaiter (personal communication, November 2019) writes that 20-25 types of chimpanzee call are now generally recognized by researchers.

Hobaiter and Byrne (2014, p. 1598) identified 15 intended outcomes expressed in chimpanzee gestures:

Stop that, move away, contact, acquire object, follow me, move closer, sexual attention (male gestures to female), sexual attention (female to male), climb on me, climb on you (infant request to adult), initiate grooming, reposition body, attend to (focus on) specific location, travel with me (adult signaller), travel with me (infant signaller).

Although the numbers of calls and gestures cited above are all qualified as estimates, chimpanzees, with an atomistic pattern of fission and fusion, do appear to have a substantially larger repertoire of calls and gestures than do vampire bats, baboons, and elephants with their more stable, molecular systems.

\section{Chimpanzees, Bonobos, and Hominins}

Sean O'Hara, Alan Bilsborough, and I have argued (2012, cf. Layton 2008, p. 116) that hunter-gatherer communities did not develop through the amalgamation of previously autonomous bands but that the regional community of hunter-gatherer societies is the human analogue of the chimpanzee community, and that bands are an intermediate, flexible level of organization that developed as human populations became more dispersed. Human adults of both sexes often freely change band membership. We therefore proposed that hunter-gatherer bands emerged as an optimal response to the increased dispersion necessitated by greater reliance on predation, yet the increased level of trust needed 
Table 2 Comparison of calls and gestures recorded by Goodall (1986) and Crockford and Boesch (2005)

\begin{tabular}{|c|c|}
\hline Goodall & Crockford and Boesch \\
\hline \multicolumn{2}{|l|}{ Calls } \\
\hline Fearful "huu" calls (fear of predator) & $\begin{array}{l}\text { Hoo: feeding, or mild fear or surprise, such as on finding an animal } \\
\text { carcass or small snake; also when travelling near nesting time. Tonal } \\
\text { bark: on seeing large snakes } \\
\text { Hoo grunt: nesting, occasionally feeding }\end{array}$ \\
\hline $\begin{array}{l}\text { Submissive calls: pant-grunts, squeaks, whimpers or screams, } \\
\text { depending on the level of distress }\end{array}$ & $\begin{array}{l}\text { Pant grunt: greeting up the hierarchy } \\
\text { Scream: receiving aggression, fear, as part of pant hoot and sometimes } \\
\text { during copulation } \\
\text { Squeak: when threatened by a dominant individual } \\
\text { Whimper: begging by infants and juveniles when being weaned or } \\
\text { separation from the mother; by young adult males when separated } \\
\text { from other males }\end{array}$ \\
\hline $\begin{array}{l}\text { Aggression is associated with graded series of calls, from soft bark to } \\
\text { bark }>\text { waa-bark }>\text { scream }\end{array}$ & $\begin{array}{l}\text { Aggression: bark (also uttered on hearing other parties of chimpanzees } \\
\text { or encountering chimpanzees from neighboring communities) } \\
\text { Hunting colobus monkeys: short bark } \\
\text { Grunt: feeding (also as greeting and close contact call at the start of } \\
\text { travel, or as a mild threat), "Aaa" grunt, deep grunt } \\
\text { Play: laughter } \\
\text { Pant: occasionally uttered during grooming or during excited feeding }\end{array}$ \\
\hline \multicolumn{2}{|l|}{ Gestures } \\
\hline $\begin{array}{l}\text { Drumming on tree trunks is frequent when chimpanzees are travelling } \\
\text { in large parties }\end{array}$ & $\begin{array}{l}\text { Travelling, display, encounters with chimpanzees from neighboring } \\
\text { communities, occasionally when arriving at large food sources }\end{array}$ \\
\hline \multicolumn{2}{|l|}{$\begin{array}{l}\text { Submissive gestures toward a more dominant individual include "pre- } \\
\text { senting" (turning rump toward dominant individual—CF baboons), } \\
\text { crouching, bowing, bobbing, embracing, mounting, reaching toward } \\
\text { or bending away }\end{array}$} \\
\hline \multicolumn{2}{|l|}{$\begin{array}{l}\text { Reassurance by dominant individual: touching, patting, embracing, } \\
\text { and grooming }\end{array}$} \\
\hline \multicolumn{2}{|l|}{$\begin{array}{l}\text { Begging for meat: reaching up to touch the meat, or holding out a } \\
\text { hand, palm upwards }\end{array}$} \\
\hline $\begin{array}{l}\text { Goodall identified } 12 \text { threatening "gestures and postures" observed at } \\
\text { Gombe (pp. 314-315). They include the "head tip," an upward jerk } \\
\text { of the chin, sitting hunched with shoulders raised and arms held out, } \\
\text { swaying vegetation, throwing rocks or sticks, and running upright at } \\
\text { an opponent }\end{array}$ & \\
\hline
\end{tabular}

to sustain the complex cooperation and reciprocity required by the hunting and gathering strategies adopted by humans.

The size of the activity groups that forage together is similar among modern human hunter-gatherers and chimpanzees, but chimpanzee parties have a much shorter maximum duration than those of hunter-gatherers, ranging from $69 \mathrm{~min}$ at Gombe (Halperin 1979) to $19 \mathrm{~min}$ in Budongo (Reynolds 2005). Unlike humans, male chimpanzees hunt animals smaller than themselves, typically monkeys (Newton-Fisher et al. 2002). Once killed, any chimpanzee (male or female) present at the place will attempt to gain some of the meat. Active or passive sharing occurs (Newton-Fisher 2007; see also Goodall 1986, pp. 279-287). Group hunts have been recorded among hunter-gatherers (net hunting among the Mbuti, fire drives in Australia; Hart and Pilling 1960, pp. 33-37, 42; Finlayson 1935, p. 44; Turnbull 1965, p. 154; Harako 1981, p. 519). Humans, however, also have a different strategy, hunting by stealth, where men go out from camp singly or in twos, to hunt larger prey. They creep up to the animal until it can be speared or shot with an arrow, then bring the meat back to camp to be shared.

The overnight camp is a defining feature of human hunter-gatherer adaptation. Chimpanzees do not assemble in this way; there are no set base camps and individuals build a new nest site wherever they find themselves at nightfall. A human band is a group whose members meet up at the end of the day, assembling at a camp site that has been prearranged and may be used for a number of days at a time. Men hunt singly or in pairs, but share meat through camp; women gather in larger groups, but provide food for their own family. The larger size of prey and frequently unpredictable occurrence of large game is thus efficiently exploited. The characteristic division of labor in the pair bond is highly dependent on wider cooperation in the band. Band residence 
Table 3 Data on: (a) \% meat consumption and population densities among chimpanzees and human hunter-gatherers living in the same environment and (b) hunter-gatherer population densities in other environments

\begin{tabular}{|c|c|c|c|c|}
\hline & $\begin{array}{l}\text { Meat consumption }(\mathrm{kg} / \\
\text { individual/day) }\end{array}$ & $\%$ Meat in $\operatorname{diet}^{\mathrm{a}}$ & Population density & Home range \\
\hline $\begin{array}{l}\text { Chimpanzee, Gombe } \\
\text { Chimpanzee, Tai Forest } \\
\text { Chimpanzee, Ngogo }\end{array}$ & $\begin{array}{l}\text { (Male) } 0.055 \\
\text { (Female) } 0.0007 \\
\text { (Male) } 0.186 \\
\text { (Female) } 0.025 \text { (Boesch } \\
\text { and Boesch-Achermann } \\
\text { 2000, p. 165) }\end{array}$ & $\begin{array}{l}2 \% \text { to } 6 \% \text { of total kilocalo- } \\
\text { ries/day (source as col } 1 \text { ) }\end{array}$ & $\begin{array}{l}2.5 / \mathrm{km}^{2} \text { (Wrangham et al. } \\
1993 \text { ) }\end{array}$ & $\begin{array}{l}\text { (Male) } 9.0-12.0 \mathrm{~km}^{2} \\
\text { (Female) } 5.8-11.0 \mathrm{~km}^{2} \\
(\text { smallest recorded range) } \\
35 \mathrm{~km}^{2} \text { (largest recorded } \\
\text { range) } \\
\text { (Source as col 3) }\end{array}$ \\
\hline H/G Mbuti & $\begin{array}{l}0.5 \text { (Ichikawa } 2005, \text { p. } 159) \\
0.45 \text { (Hart } 1978 \text { in Kelly } \\
1995, \text { p. } 103) \\
1.06 \text { (Tanno } 1976 \text { in Kelly } \\
1995 \text {, p. } 103 \text { ) }\end{array}$ & $\begin{array}{l}\text { 30\% (Ichikawa 2005, p. } \\
\text { 159; Hart 1978; Tanno } \\
1976 \text { in Kelly 1995) }\end{array}$ & $\begin{array}{r}0.17-0.2 \mathrm{~km}^{2} \text { (Turnbull } \\
1962 ; \text { Ichikawa 2005) }\end{array}$ & $\begin{array}{l}260 \mathrm{~km}^{2} \text { (Turnbull 1965, p. } \\
\text { 134, cited Abruzzi 1980, } \\
\text { p. } 22 \text { ) }\end{array}$ \\
\hline $\mathrm{H} / \mathrm{G}$ Aka & & & $\begin{array}{l}0.017 \mathrm{~km}^{2} \text { (Hewlett et al. } \\
1982) \\
0.28 \mathrm{~km}^{2} \text { (Bahuchet } 1988 \\
\text { in Kelly 1995) }\end{array}$ & $\begin{array}{l}490 \mathrm{~km}^{2} \text { or more }(\text { Hewlett } \\
\text { et al. } 1982, \text { pp. } 422,424)\end{array}$ \\
\hline H/G Ache & $\begin{array}{l}\text { 1.78 (Kaplan et al. 1985, } \\
\text { cited Kelly 1995, p. } 103 \text {; } \\
\text { Hill and Hurtado 1996, } \\
\text { p. } 65 \text { ) }\end{array}$ & $87 \%($ Source as col 1$)$ & & \\
\hline \multicolumn{5}{|c|}{$\begin{array}{l}\text { In savanna and semi-desert } \\
\text { environments }\end{array}$} \\
\hline H/G Hadza & $\begin{array}{l}<1.00 \text { (O’Connell et al. } \\
\text { 2002, p. 858) }\end{array}$ & $50 \%($ Source as col 1$)$ & & \\
\hline H/G Ju'hoansi & $0.256($ Lee 1979, p. 265$)$ & $30 \%($ Source as col 1$)$ & & \\
\hline H/G G/wi & $\begin{array}{l}0.03 \text { October } 0.22 \text { (Sil- } \\
\text { berbauer January-June } \\
\text { 1972, p. 285) }\end{array}$ & $30 \%($ Source as col 1$)$ & & \\
\hline $\begin{array}{l}\text { Australian Western } \\
\text { Desert }\end{array}$ & $\begin{array}{l}0.56 \text { (Gould } 1980 \text { in Kelly } \\
1995, \text { p. } 103 \text { ) }\end{array}$ & $15-30 \%$ (Source as col 1) & & \\
\hline
\end{tabular}

${ }^{a}$ For further details of how contribution of meat to diet was calculated, see notes to Layton and O’Hara (2010, Table 5.2)

confers a number of further advantages such as alloparenting, prior rights over other bands to forage in the surrounding country, and information exchange.

The predatory nature of human subsistence compels a lower population density than chimpanzees can sustain (see Table 3) forcing the community to disperse. The persistence of the larger community can be explained by the need to keep membership options in a number of bands open. The success of the band as a social unit demands a high level of reciprocal altruism and mutual trust. The ability to move between bands if disputes break out, or if resources in the band territory are temporarily depleted, makes membership of a wider community adaptive. The band territory rarely enables self-sufficiency in subsistence resources. The community is an aggregation of bands between which individuals can move with a minimum of formality, within which most marriages take place, and which is frequently characterized by a distinct dialect or language. Persistence of the community is facilitated by a number of distinctively human traits: gift giving, inter-band marriage, classificatory kinship, and language.

\section{The Evolution of Human Hunter-Gatherer Fission-Fusion Society}

\section{African Homo erectus}

Although the hominin line evolved in parallel with baboons, it had several differentiating characteristics, including the flexible, atomistic form of fission-fusion behavior and a diet that included meat. Based on changes in the shape of the rib cage, Aiello and Wheeler (1995) dated the origin of an increased proportion of meat in the diet to the appearance of $H$. erectus, between 1.8 and 1.6 million years ago. However, Alan Bilsborough (in Layton et al. 2012) argued that it is unlikely $H$. erectus social life possessed all the features of modern band life, including lengthy pair bonding and alloparenting. Tooth enamel formation rates in all 
early Homo species were ape-, not human-like, implying rapid dental development (Dean et al. 2001). Homo erectus fossils indicate appreciable sexual dimorphism, implying intense male-male competition, with multiple matings and only brief pair-bonding. In other words, they imply a continuing ancestral mating pattern, and decidedly non-modern social organization.

Bilsborough pointed out that the Gona pelvis sheds further light on the social behavior of $H$. erectus. It could accommodate a neonate's brain of up to $315 \mathrm{~cm}^{3}$, that is, $30-50 \%$ of adult $H$. erectus brain size. This suggests that proportionately more of adult brain growth occurred prenatally than is the case with modern humans. This conclusion also accords with findings of $H$. erectus postnatal growth as revealed by dental analysis of the Nariokotome skeleton, which points to an age at death around 8 years yet skeletal development and muscularity are equivalent to a modern 13- or 14-year-old. In other words, compared with modern humans, $H$. erectus displays evidence of relatively rapid physical development within an abbreviated time span, and less need for extended child care. Sexual dimorphism and a shorter period of childhood dependency suggest lengthy pair bonding was unlikely.

\section{Could Homo erectus Speak?}

Speech travels further than gestures within a camp; anthropologists who have worked with native Australians find that women join in conversations across the camp throughout the night. Speech would enable negotiation and planning (dialogue), the extension of social kinship more widely and differentiation of a greater number of roles, and reference to relatives with whom one is not face to face.

African $H$. erectus communities may not have been highly dispersed. The closest ethnographic parallel to the ecology of early $H$. erectus is provided by the Hadza, who live within the area once populated by $H$. erectus (O'Connell et al. 2002). The Hadza live at a relatively high population density (for hunter-gatherers) of one person per 4-6.5 km² (Woodburn 1972, pp. 193-194; Blurton Jones et al. 1992). Remarkably, an African H. erectus community of 110 individuals (as predicted by Dunbar's 1993 analysis of relative prefrontal cortex brain size) living at such a density could occupy a territory of $12-15 \mathrm{~km}$ radius, equal to the Hadza hunter's daily range from camp (Hawkes et al. 1997, p. 555). This scale of interaction appears largely mirrored in the movement of stone materials. Figure 12 in Féblot-Augustins (1997) shows that during the period from 1.2 to 0.2 million years ago $73 \%$ of African hominin tool depositions occurred within $15 \mathrm{~km}$ of their source and $90 \%$ within $25 \mathrm{~km}$ (for further discussion, see Layton et al. 2012).

MacLarnon and Hewitt (2004) point out that, in speech, several sounds can be emitted in a sequence within one breath, which is not possible in primate calls. The skill demands fine thoracic nerve control, which is evidenced in a widening of the thoracic and last cervical vertebral canal, found in modern humans and Neanderthals, but not erectus. The presumption is therefore that these anatomical adaptations appeared in the common ancestor of the two species, namely Homo heidelbergensis. Dediu and Levinson (2018) reach the same conclusion, but arguing from the evidence of the approximately 20 full or partial Neanderthal genomes now available, which show that the genetic differences between Neanderthals, modern humans, and Denisovans are "very modest indeed" (2018, p. 51).

It is conceivable, especially in light of the complex social behavior of chimpanzees and bonobos, that $H$. erectus social life could have been sustained without language, only with calls and gestures.

People engage in verbal fights, provocative or impressive word displays, protesting interruptions, reconciliatory remarks, and many other patterns of activity which chimpanzees perform without an accompanying text. (de Waal 1982, p. 149)

There would, however, have been strong selection pressure favoring more complex forms of communication. Two recent studies suggest an evolutionary pathway to speech.

The bonobo whistle and high hoot $(\mathrm{W}+\mathrm{HH})$ combination is cited by Schamberg et al. (2016, p. 115) as an example of how the uncertainty created by atomistic fission-fusion may create situations in which contact calls that only provide information about identity and location are insufficient to facilitate effective group movement. "Bonobos must frequently decide which social partners to associate with and which resources to exploit. These decisions depend on the behaviour... of other, out of sight individuals, creating an unstable, and potentially confusing, environment." The $\mathrm{W}+\mathrm{HH}$ call combination is uttered by an individual when two parties converge. The call is produced intentionally, not (in the sense used in this article) spontaneously. It appears to express the caller's desire to join the other party, because the caller is more likely to transfer after calling, particularly if it receives an answering call from the other party. If no answering call is received in response, the caller may repeat its $\mathrm{W}+\mathrm{HH}$.

Hobaiter and Byrne (2014) studied the use of gestures by wild chimpanzees, and found that chimpanzees clearly use gestures, unlike calls, intentionally. They confirmed this by noting that chimpanzees continued gesturing until they were satisfied with the recipient's response.

In light of these examples, I tentatively suggest a twopronged pathway to speech. At the physiological level, increasingly more refined calls of the $\mathrm{W}+\mathrm{HH}$ type could have selected for finer motor control of vocalizations, while the existing corpus of intentional gestures could have 
provided the scaffolding to which the meaning of words might have been attached.

Willems and van Schaik (2017) propose that H. erectus social life was on the cusp of male-female bonding and band formation. They note that where primates suffer a high risk of predation, there are more males in the group, which leads to the survival of a higher proportion of immature individuals. In larger groups, they argue, it is harder for dominant males to monopolize mating, so it becomes adaptive for other males to join the group. Dominant males may concede sexual access because cooperation in attacking predators is essential. They argue this would select for less sexual dimorphism.

\section{Homo heidelbergensis}

Several independent sources of evidence support the conclusion that language originated during the evolution of $H$. heidelbergensis. The evidence deduced by MacLarnon and Hewitt, and Dediu and Levinson, is cited above. Dunbar (1993) points out that the major increase in hominin brain size does not take place until the appearance of $H$. heidelbergensis (c. 700,000 years before present). A reduction in sexual dimorphism indicates weaker selection for male-male competition, and a longer period of childhood is associated with a more pronounced adolescent growth spurt that occurred between 1 million and 500,000 years ago, and is also characteristic of $H$. heidelbergensis. This implies pair bonding was emerging. Layton et al. (2012) suggested that at this stage of hominin evolution the large brain permitted $H$. heidelbergensis to simultaneously adapt his/her foraging strategies, and coordinate and monitor social relationships over an increasingly fluid and dispersed network of bandmates. This is the point at which use of language to differentiate between kin standing in different relationships to one another, and their appropriate roles, and to talk about (among many other topics) past and future cooperation, or about a friend or relative who is not present, probably began.

Sterelny (this volume) describes $H$. heidelbergensis as the originators of "open-textured social organization" and cites the acceleration of cumulative cultural evolution (evidenced in the succession of stone tool cultures) during the last 150,000 years as evidence for open social networks. He points out that among chimpanzees, only a subadult female could have transferred cultural traits from one community to another, whereas modern hunter-gatherers freely change band membership as adults, even between neighboring communities.

These arguments imply that a complex process of coevolution took place between cognition, physiology, and social strategies which would have taken a considerable time, probably culminating at the Lower to Middle Paleolithic transition. Malinsky-Buller and Hovers (2019) estimate that the transition between the Lower and Middle Paleolithic in East Africa took between 100,000 and 200,000 years, concluding about 250,000 years BP. Stiner's excavations at Qesem Cave in the southern Levant seem to capture this transformation midway. Deposits from between 400,000 and 200,000 years вP provide "evidence for deferred benefits, divided foraging efforts from a central place, cooking and, presumably, meat sharing" (Stiner et al. 2011, p. 229).

Both baboons and chimpanzees have some cognitive skills that would have facilitated the evolution of language. Despite their limited vocabulary of calls, baboons have "an almost open-ended ability to learn new sound-meaning pairs" (Cheney and Seyfarth 2007, p. 257). Some individual Gombe chimps show expressions never seen in others (Goodall 1986, p. 125), yet these are correctly interpreted by others.

I was struck, during fieldwork at Uluru, central Australia, in the 1970s, by remarks assimilating more distant relationships to closer ones. "When I was a child I used to walk with my family to [the base camp of another band] where I had a lot of cousins I called brother," or, from another senior man, "I called Napala and Tjalkalyiri brother because my father Lunkata and their mother Antumara were like brother and sister... always travelling together" (although in fact Lunkata was Antumara's mother's brother's son; Layton 1995, p. 225). Most tellingly, the word walytja in the local language (Pitjantjatjara) means a kinsperson or someone you care for. Relationships modelled on kinship are extended among the $\mathrm{Ju} /$ 'hoansi and Netsilik through the recognition of namesakes, where two individuals with the same personal name treat each other as siblings (Barnard 1992, pp. 265-281). Among the Netsilik, namesakes exchanged gifts that had to be identical, such as a knife for a knife; the exchanges were not carried out for material benefit but "to give expression to...enduring friendliness" (Balikci 1970, p. 139).

While language may have facilitated extending social networks beyond close kin, it certainly did not originate social kinship. Relationships of reciprocal altruism between nonkin are found among vampire bats, chacma baboons, chimpanzees, and bonobos. There is, correspondingly, a deep connection between mammals' need (in the absence of the close genetic kinship possessed by social insects) to maintain social relationships, and the value of signaling friendly intent. I proposed that the more uncertain the current state of social relationships, the greater the need for information conveyed by calls and gestures, and that such uncertainty would have been particularly acute in a species with an atomistic fission-fusion society living at low population densities, yet highly dependent on reciprocal altruism. The ancient connection between transmission of information and relationships built on trust underpins the coevolution of language and social kinship. 
Acknowledgements I'm grateful to Alan Bilsborough, Cat Hobaiter, Ann MacLarnon, Kim Sterelny, and Jo Setchell, for providing additional references and helpful comments on the draft version of this paper.

Open Access This article is licensed under a Creative Commons Attribution 4.0 International License, which permits use, sharing, adaptation, distribution and reproduction in any medium or format, as long as you give appropriate credit to the original author(s) and the source, provide a link to the Creative Commons licence, and indicate if changes were made. The images or other third party material in this article are included in the article's Creative Commons licence, unless indicated otherwise in a credit line to the material. If material is not included in the article's Creative Commons licence and your intended use is not permitted by statutory regulation or exceeds the permitted use, you will need to obtain permission directly from the copyright holder. To view a copy of this licence, visit http://creativecommons.org/licenses/by/4.0/.

\section{References}

Abruzzi WS (1980) Flux among the Mbuti pygmies of the Ituri Forest. In: Ross EB (ed) Beyond the myths of culture. Academic, New York, pp 3-31

Aiello L, Wheeler P (1995) The expensive-tissue hypothesis: the brain and digestive system in human and primate evolution. Curr Anthropol 36:199-221

Aureli F, Schaffner C, Boesch C, Bearder S, Call J, Chapman C et al (2008) Fission-fusion dynamics: new research frameworks. Curr Anthropol 49:627-654

Balikci A (1970) The Netsilik Eskimo. Garden City, New York

Barnard A (1992) Hunters and herders of Southern Africa: a comparative survey. Cambridge University Press, Cambridge

Bateson G (1973) Redundancy and coding. In: Bateson G (ed) Steps to an ecology of mind. Paladin, St Albans, pp 387-401

Blurton Jones N, Smith LC, O'Connell J, Hawkes K, Kamuzora C (1992) Demography of the Hadza, an increasing and high-density population of savanna foragers. Am J Phys Anthropol 98:159-181

Boesch C, Boesch-Achermann H (2000) The chimpanzees of the Tai Forest. Oxford University Press, Oxford

Carter G, Wilkinson G (2016) Common vampire bat contact calls attract past food-sharing partners. Anim Behav 116:45-51

Cheney D, Seyfarth R (2007) Baboon metaphysics: the evolution of a social mind. University of Chicago Press, Chicago

Cherry C (1966) On human communication, 2nd edn. MIT Press, Cambridge

Crockford C, Boesch C (2005) Call combinations in wild chimpanzees. Behaviour 142:397-421

De Waal F (1982) Chimpanzee politics: power and sex among apes. Johns Hopkins University Press, Baltimore

Dean C, Leakey MG, Reid D, Schrenk F, Schwartz GT, Stringer C, Walker A (2001) Growth processes in teeth distinguish modern humans from Homo erectus and earlier hominins. Nature 414:628-631

Dediu D, Levinson S (2018) Neanderthal language revisited: not only us. Curr Opin Behav Sci 21:49-55

Dunbar RIM (1989) Social systems as optimal strategy sets: the costs and benefits of sociality. In: Standen V, Foley R (eds) Comparative socioecology: the behavioural ecology of humans and other mammals. Blackwell Scientific Publications, Boston, pp 131-149

Dunbar RIM (1993) Co-evolution of neocortical size, group size and language in humans. Behav Brain Sci Evol 16:681-735

Féblot-Augustins J (1997) La circulation des matières premières au Paléolithique. ERAUL 75, Liège
Finlayson H (1935) The Red Centre. Angus and Robertson, Sydney

Fischer J, Price T (2017) Meaning, intention, and inference in primate vocal communication. Neurosci Biobehav Rev 82:22-31

Godfrey-Smith P (2007) Information in biology. In: Hull DL, Ruse M (eds) The Cambridge guide to the philosophy of biology. Cambridge University Press, Cambridge, pp 103-119

Godfrey-Smith P (2015) Primates, cephalopods, and the evolution of communication. In: Platt M (ed) R. Seyfarth and D. Cheney, the social origins of language. Princeton University Press, Princeton, pp 103-120

Goodall J (1986) The chimpanzees of Gombe: patterns of behavior. Bellnap, Cambridge

Gould R (1980) Living archaeology. Cambridge University Press, Cambridge

Griesser M, Drobniak S, Nakagawa S, Botero C (2017) Family living sets the stage for cooperative breeding and ecological resilience in birds. PLoS Biol 15(6):e2000483

Halperin S (1979) Temporary association patterns in free ranging chimpanzees: an assessment of individual grouping preferences. In: Hamburg DA, McCown EM (eds) The great apes. Menlo Park, Benjamin/Cummings, pp 491-499

Hamilton WD (1964) The genetical evolution of social behavior, I, II. J Theor Biol 7:1-52

Harako R (1981) The cultural ecology of hunting behaviour among Mbuti pygmies. In: Harding RVO, Teleki G (eds) Omnivorous primates. Columbia University Press, New York, pp 499-555

Hart J (1978) From subsistence to market: a case study of the Mbuti net hunters. Hum Ecol 6:325-353

Hart C, Pilling A (1960) The Tiwi of north Australia. Holt, Rinehart, New York

Hawkes K, Bliege-Bird R (2002) Showing off, handicap signalling and the evolution of men's work. Evol Anthropol 11:58-67

Hawkes K, O'Connell JF, Blurton Jones NG (1997) Hadza women's time allocation. Curr Anthropol 38:551-577

Hewlett B, van der Koppel J, Cavalli-Sforza L (1982) Exploration ranges of Aka pygmies of the Central African Republic. Man 17:418-430

Hill K, Hurtado M (1996) Ache life history: the ecology and demography of a foraging people. Aldine de Gruyter, Hawthorne

Hobaiter C, Byrne R (2014) The meaning of chimpanzee gestures. Curr Biol 24:1596-1600

Hockett C, Ascher R (1964) The human revolution. Curr Anthropol 5:135-168

Ichikawa M (2005) Food sharing and ownership among central African hunter-gatherers: an evolutionary perspective. In: Widlok T, Tadesse WG (eds) Property and equality: ritualisation, sharing, egalitarianism, vol 1. Berg, Oxford, pp 151-164

Kaplan H, Hill K, Cadeliña R, Hayden B, Hyndman DC, Preston RJ, Smith EA, Stuart DE, Yesner DR (1985) Food sharing among Ache foragers: tests of explanatory hypotheses. Curr Anthropol 26:223-246

Kano T (1992) The last ape: pygmy chimpanzee behaviour and ecology (translated by E.O. Vineberg). Stanford University Press, Stanford

Kelly R (1995) The foraging spectrum. Smithsonian, Washington, DC

Kersken V, Gómez J-C, Liszkowski U, Soldati A, Hobaiter C (2019) A gestural repertoire of 1- to 2-year old children: in search of the ape gestures. Anim Cogn 22(4):577-596

Kummer H (1968) Social organization of Hamadryas Baboons: a field study. Bibliotheca Primatology, No. 6. University of Chicago Press, Chicago

Layton R (1995) Relating to the country in the Western Desert. In: Hirsch E, O'Hanlon M (eds) The anthropology of landscape: perspectives on place and space. Clarendon, Oxford, pp 210-231

Layton R (2000) Anthropology and history in Franche-Comte. Oxford University Press, Oxford 
Layton R (2008) What can ethnography tell us about human social evolution? In: Allen N, Callan H, Dunbar R, James W (eds) Early human kinship: from sex to social reproduction. Blackwell, Malden, pp 113-127

Layton R, O'Hara S (2010) Human social evolution: a comparison of hunter-gatherer and chimpanzee social organisation. In R. Dunbar, C. Gamble and J. Gowlett (eds), Social brain, distributed mind. Proc Br Acad 158:83-113

Layton R, O’Hara S, Bilsborough A (2012) Antiquity and social function of multi-level social organisation among human hunter-gatherers C Grueter, I Matsuda, Z Peng and D Zinner (eds). Int J Primatol 33(5):1215-1245

Lee RB (1979) The !Kung San: men, women and work in a foraging society. Cambridge University Press, Cambridge

Lee P, Fishlock V, Webber E, Moss C (2016) The reproductive advantages of a long-life: longevity and senescence in wild female African elephants. Behav Ecol Sociobiol 70(3):337-345

MacLarnon A, Hewitt G (2004) Increased breathing control: another factor in the evolution of human language. Evol Anthropol 13:181-197

Malinsky-Buller A, Hovers E (2019) One size does not fit all: group size and the Late Middle Pleistocene prehistoric archive. J Hum Evol 127:118-132

Maynard-Smith J (1994) Must reliable signals always be costly? Anim Behav 47:1115-1120

Moss C, Croze H, Lee P (2011) The Amboseli elephants: a long-term perspective on a long-lived mammal. University of Chicago Press, Chicago

Newton-Fisher N (2007) Chimpanzee hunting behaviour. In: Henke W, Tattersall I (eds) Handbook of paleoanthropology. Springer, Berlin, pp 1295-1320

Newton-Fisher NE, Notman H, Reynolds V (2002) Hunting of mammalian prey by Budongo Forest chimpanzees. Folia Primatol 73(5):281-283

O'Connell JF, Hawkes K, Lupo KD, Blurton Jones NG (2002) Male strategies and Plio-Pleistocene archaeology. J Hum Evol 43:831-872

Reynolds V (2005) The chimpanzees of the Budongo Forest. Oxford University Press, Oxford

Schamberg I, Cheney D, Clay Z, Hohmann G (2016) Call combinations, vocal exchanges and interparty movement in wild Bonobos. Anim Behav 22:109-116

Scott-Phillips T (2008) Defining biological communication. J Evol Biol 21:387-395

Seyfarth RM, Cheney D (2012) The evolutionary origins of friendship. Annu Rev Psychol 63:153-177

Shannon C (1948) A mathematical theory of communication. Bell Syst Tech J 27:379-423
Silberbauer G (1972) The G/wi bushmen. In: Bicchieri MG (ed) Hunters and gatherers today. Holt, Rinehart and Winston, New York, pp 271-326

Stiner M, Gopher A, Barkai R (2011) Hearth-side socioeconomics, hunting and paleoecology during the Late Lower Paleolithic at Qesem Cave, Israel. J Hum Evol 60:213-233

Swedell L, Plummer T (2012) A papionin multilevel society as a model of hominin social evolution. Int J Primatol 33:1165-1193

Tanno T (1976) The Mbuti net-hunters in the Ituri Forest, Eastern Zaire- their hunting activities and band composition. Kyoto Univ Afr Stud 10:101-135

Trivers R (1971) The evolution of reciprocal altruism. Q Rev Biol $46: 35-57$

Trivers R (1985) Social evolution. Benjamin/Cummings, Menlo Park

Turnbull C (1962) The forest people. Simon and Schuster, New York

Turnbull CM (1965) Wayward servants: the two worlds of the African pygmies. Greenwood, Westport

Van Schaik CP, Kappeler P (1993) Life history, activity period and lemur social systems. In: Kappeler PM, Ganzhörn JU (eds) Lemur social systems and their ecological basis. Plenum Press, New York, pp 241-260

Wilkinson G (1984) Reciprocal food sharing in vampire bats. Nature 309:181-184

Wilkinson GS, Carter G, Bohn KM, Caspers B, Chaverri G, Farine D et al (2019) Kinship, association, and social complexity in bats. Behav Ecol Sociobiol 73:7

Willems E, van Schaik C (2017) The social organisation of Homo ergaster: inferences from anti-predator responses in extant primates. J Hum Evol 109:11-21

Woodburn J (1972) Ecology, nomadic movement and the composition of the local group. In: Ucko P, Tringham R, Dimbleby GW (eds) Man, settlement and urbanism. Duckworth, London, pp 193-206

Wrangham RW, Gittleman JL, Chapman CA (1993) Constraints on group size in primates and carnivores: population density and dayrange as assays of exploitation competition. Behav Ecol Sociobiol 32(3):199-209

Zahavi A (1975) Mate selection: a selection for a handicap. J Theor Biol 53:205-214

Zuberbühler K (2002) A syntactic rule in forest monkey communication. Anim Behav 63:293-299

Publisher's Note Springer Nature remains neutral with regard to jurisdictional claims in published maps and institutional affiliations. 